\title{
Article
}

\section{TRAUMA, PREJUDICE, LARGE-GROUP IDENTITY AND PSYCHOANALYSIS}

\author{
Vamık D. Volkan ${ }^{1}$
}

Escaping Nazi annexation of Austria, Sigmund Freud and his family left there in 1938 to live the rest of their lives in exile in the house now known as the Freud Museum in London. This paper is based upon the author's Holocaust Day Memorial Lecture delivered virtually at this museum on January 27, 2021, which marked the 75th anniversary of the liberation of AuschwitzBirkenau, the largest Nazi death camp. Besides remembering those who were lost during World War II, the content of this paper includes a description of different types of massive traumas, with a focus on disasters at the hand of the Other, and their impact on individuals and large groups. Sigmund Freud's ideas about relationships between communities and countries with adjoining territories, as well as large-group psychology, are updated, and individuals' and large groups' needs to grasp onto large-group identities is explained and illustrated with case reports.

KEY WORDS: minor differences; chosen trauma; entitlement ideology; time collapse; dehumanization; purification; transgenerational transmissions; largegroup mourning; COVID-19; Holocaust Day Memorial Lecture; Freud Museum in London

https://doi.org/10.1057/s11231-021-09285-z

\section{AN UNNAMED CHILDHOOD FEELING ABOUT THE NAZIS}

On January 27, 1945, when Auschwitz-Birkenau Nazi Concentration Camp was liberated in Germany I was a 12-year-old son of Turkish parents living on Cyprus, which was then a British colony. At that time there were about 350,000 people on this Mediterranean island. Two ethnic groups, Greeks and, in lesser numbers, Turks lived in the same cities, towns and some villages, while in other villages only Greeks or Turks lived. There were also smaller numbers of Armenians, Maronites, Phoenicians and British.

Vamık D. Volkan, M.D., is an Emeritus Professor of Psychiatry at the University of Virginia, Charlottesville.

Address correspondence to Vamik D. Volkan, University of Virginia, 1909 Stillhouse Road, Charlottesville, VA 22901, USA.

*A version of this paper was given at the Freud Museum, London, to commemorate the Annual Holocaust Day on January 27, 2021. 
After World War II started when I was seven years old, thousands of Cypriot Greeks and Cypriot Turks joined the British military. Now and then German or Italian war planes would fly over Cyprus and bomb the British bases on the island. After the Nazis conquered Crete, another Mediterranean island, in May of 1941 when I was eight-and-a-half years old, there was great anxiety and expectation among Cypriots that the Nazis would try to capture Cyprus next. Turban-wearing Sikh soldiers from India who had joined the British military forces roamed the streets of Nicosia, the capital city where my family lived. We learned how to put on gas masks and were given tasteless black bread to eat. We dug a bomb shelter in our garden. When alarms went off, day or night, rain or shine, my parents, my two sisters and I would take refuge there until the all-clear sounded.

As a youngster I did not have a name for my unpleasant feeling, my anxiety, which became my companion after my father brought a particular book to the house and locked it in a big wooden box where he kept other books. My older sisters told me that the new book was a German dictionary, and it was my father's plan that when the Nazis came to the island, he would talk with them in German and ask them not to hurt his children. My sisters also told me that my father had done something forbidden when he bought the German book. Today I do not know if buying a German dictionary was a criminal act, but at that time I believed that my father had done something illegal to protect us. This circumstance confirmed for me that the Nazi invasion surely would take place.

During my first year in an elementary school in Nicosia, while playing with other children, I witnessed an Italian war plane explode above us after it was shot by a British fighter plane, a Spitfire. I watched the Italian pilot parachuting down. Adults and children rushed to the area where the plane had fallen and collected items to remember the event. I do not recall who gave me a small piece of glass from the crushed airplane, but I kept this piece of glass with me for decades. Much later in my life, after I became a psychoanalyst, I wrote about "linking objects and linking phenomena" (Volkan, 1981). I then realized that this piece of glass was a kind of "linking object" connecting me to a fearful day in my life during which I suddenly lost my sense of security while playing with my schoolmates. By having ownership of this piece of glass and the ability to control it I could externalize and master my bewilderment. Slowly the piece of glass lost its "magic," but I continued to keep it even after I went to Turkey to study medicine when I was 18 years old. I left it behind when I came to the United States in early 1957, a few months after I graduated from medical school. I did my psychiatric training in the United States, settled in this new location, and later became a psychoanalyst. 
Before migrating to the United States, I did not have any close Jewish acquaintances. My knowledge of the Holocaust came from seeing movies related to it and reading about this unbelievable tragedy. Early in my psychiatric training I had a patient who would often cry during his sessions with me. His crying was a silent crying. I could see him crying intensely, but I would not hear him. I learned that his family had hidden in the attic of a house belonging to a Christian family in a European location under Nazi occupation. As an infant he had to sleep in a drawer of an old chest. One day Nazi soldiers came to the house looking for hidden Jewish people. When the baby started to cry, his father put his hand over the infant's mouth, afraid that the Nazi soldiers would hear his son's crying. Of course, my patient as an adult did not remember this incident, but while he was growing up the family would refer to it again and again. Working with this young man and later other Jewish patients like him connected me emotionally to the history of the Holocaust (Volkan, 2020a).

Today, Nazis do not rule Germany; it is a democratic country. But today, due to a bloody ethnic conflict, Cypriot Turks and Cypriot Greeks are separated from one another, and the island is divided into Turkish and Greek sections. Also due to this conflict, a young Cypriot Turkish medical student, Erol, who was like a brother to me, was shot and killed by a Cypriot Greek terrorist. During the last two years of my medical school days in Turkey I shared a one-room apartment with Erol, who was a year younger than I. Some months after my arrival in the United States Erol had gone to the island to look after his ailing mother. While at a pharmacy buying medicine for her, he was killed-not for personal reasons, but for inducing fear within members of an opposing ethnic group.

Since the beginning of human history large groups have been allies and enemies with other large groups. I use the term "large group" to refer to thousands or millions of people, most of whom will never see or even know about each other as individuals, but who share many of the same sentiments. Membership to tribal, ethnic, national and religious large groups all over the world begins in childhood. However, religious cults such as Aum Shinrikyo and the Branch Davidians, terrorist organizations such as Al-Qaeda and so-called Islamic State ISIS, and extreme ideological organizations such as white supremacist groups in the United States or PEGIDA (European Patriots against the Islamization of the Occident) in Germany represent large groups to which membership takes place in adulthood. These individuals as adults exaggerate selected aspects of their childhood large-group identities by holding on to a restricted special nationalistic, religious, or ideological belief, or they become believers in ideas that were not available in their childhood environments (Volkan, 2020b; Suistola \& Volkan, 2017). 
People refer to their large-group identities-whether such identities evolved in childhood or were found in adulthood-such as "we are Apaches," "we are Jewish people in Lithuania," "we are members of the Ku Klux Klan," "we are Arabs," "we belong to the United Kingdom," "we are French," "we are Catholics," or "we are followers of communist ideology."

\section{COMMUNITIES WITH ADJOINING TERRITORIES}

We can start examining the psychology of large groups by remembering Sigmund Freud's remarks about "narcissism of minor differences." In 1917 Freud wrote: "It is always possible to bind together a considerable number of people in love, so long as there are other people left over to receive the manifestation of their aggressiveness" (p. 114). He went on to describe how communities "with adjoining territories" such as the Spaniards and the Portuguese, the North Germans and the South Germans, or the English and Scotch, are engaged in feuds and ridicule each other. Freud added that narcissism of minor differences "is a convenient and relatively harmless satisfaction of the inclination to aggression, by means of which cohesion between the members of the community is made easier" (Freud, 1917, p. 114).

David Werman (1988) reviewed Freud's description of "narcissism of minor differences" and stated that, "In contrast to Freud's observation that the narcissism of minor differences is relatively harmless, I suggest that in the social sphere it harbors the potential for a pernicious escalation into hostile and destructive actions on a widespread scale" (p. 451). There are examples in the literature to support Werman's remarks. For example, law and political science professor Donald Horowitz (1985) described how Sinhalese mobs in the Sri Lankan riots of 1958 relied on a variety of subtle indicators - such as the presence of earring holes in the ear or the manner in which a shirt was worn-to identify their enemy, Tamils, whom they then attacked or killed. In Cyprus, Greek and Turkish shepherds used to dress in an identical manner, except that a Greek shepherd's cloth belt was blue and the Turkish shepherd's red. During their ethnic conflict this minor difference would invite death.

Here is another consideration related to Freud's remarks about communities and countries "with adjoining territories." Since his time the description of such communities has changed drastically. When empires existed, and during colonialism, one large group's administrators ruled territory inhabited by indigenous people. At the present time, the development and incredible proliferation of communication, travel and military technologies, electronic commerce (Kosiur, 1997), language and artificial 
intelligence (Bolter, 1984), and a neighbor-like psychology, regardless of actual physical proximity, are realities all over the world between independent countries. For example, North Korea's missiles and the United States Navy's activities in the Yellow Sea or Sea of Japan, in a psychological sense, make the United States and North Korea neighbors, and the United States and Iran can behave like two rivals living next door to each other (Suistola \& Volkan, 2017).

This new type of neighborhood has been linked to "globalization," which during the last few decades has become the buzzword in political as well as academic circles. It personifies a wish for societal prosperity and well-being by standardizing economic and political elements and by making democratic freedom universal. However, some scholars, as early as two decades ago, began noticing that globalization also includes malignant prejudice, racism, and an indifference to large-group identities (Çevik, 2003; Kinnvall, 2004; Ratliff, 2004; Morton, 2004; Liu \& Mills, 2006; Stapley, 2006).

One political leader's reference to communities "with adjoining territories" is well known. On November 19, 1977 Anwar Sadat came to Israel, and during his speech at the Knesset he referred to a "psychological wall" accounting for 70 percent of the problems between Arabs and Israelis. Sadat's speech led to an unusual opportunity for me to study psychological walls that existed in many locations, worlds away from my accustomed place behind the psychoanalytic couch (Volkan, 1988, 1997, 2004, 2006a, 2013).

\section{LARGE-GROUP IDENTITY}

Sigmund Freud did not focus on the concepts of individual and large-group identity, but he referred to it indirectly and noted that parents represent the greater society to their child (Freud, 1938). Unlike an individual's character and personality, which are observed and perceived by others, such as psychoanalysts and other therapists, individual identity refers to an individual's inner working model-this person, not an outsider, senses and experiences it. Erik Erikson (1956) defined the individual identity as a persistent sense of sameness within oneself, while sharing some characteristics with other individuals. Salman Akhtar (1992, 1999) wrote that the sustained feeling of inner sameness is accompanied by a temporal continuity in the self-experience: the past, the present, and the future are integrated into a smooth continuum of remembered, felt, and expected existence for the individual. Akhtar also described how individual identity is connected with a realistic body image and a sense of inner solidarity, 
associated with the capacity for solitude and clarity of one's gender and linked to large-group identity.

Earlier, in a paper published in this journal, I described in detail how a child's large-group identity develops (Volkan, 2019). Here I will give a brief description. Scientific studies of recent decades have shown that there is a psychobiological potential of we-ness and bias toward one's own kind that exists in the early months and years of a child's life (Stern, 1985; Greenspan, 1989; Emde, 1991; Lehtonen, 2003; Purhonen et al., 2005; Bloom, 2010). Among the factors that help children to stop being "generalists" (Erikson, 1956) and absorb their large-group identity, we consider their identifications with the parents' and other important persons' narcissistic investments in their own large-group identities, as well as prejudices about Others. Psychoanalytic studies about transgenerational transmissions also illustrate how parents and other important adults deposit images and ego tasks in children's developing identities. Knowledge of transgenerational transmissions of Holocaust-related images and ego functions from one generation to the next mainly comes from studies on Jewish survivors of the Holocaust and their offspring (Grubrich-Simitis, 1979; Kogan, 1995; Kestenberg \& Brenner, 1996; Laub \& Podell, 1997; Volkan, Ast, \& Greer, 2002; Brenner, 2014, 2019; Grünberg \& Markert, 2017; Laub, 2018). Children also experientially learn what belongs to their large group and what does not (Volkan, 2013). Imagine a Muslim child going to a picnic with his family members next to a farm that belongs to a Christian. The child sees little pigs and wants to touch them. The child's Muslim grandmother then says "No. Don't go near a pig. Pigs do not belong to our kind of individuals. We do not eat pork." For this Muslim child, the pig becomes a reservoir for externalizing permanently his or her unintegrated and "unwanted" self and internalized object images. Children also externalize their good unintegrated images into their own cultural, historical, ethnic, national and religious elements. Kilts and bagpipes become large-group symbols for Scottish large-group identity. Saunas assume a psychological connection to being Finnish.

\section{SIGMUND FREUD'S “GROUP PSYCHOLOGY" AND THE TENT METAPHOR}

Now I will briefly summarize Sigmund Freud's "group psychology" and then add new perspectives on his ideas. He did not consider mere collections of people to be a group, and described race, nations, religious or professional organizations as groups. He illustrated that in spite of the differences between the church and the army, each has a head (Jesus Christ and commander-in-chief) who rules and treats all individuals with equal 
love. In turn, the members idealize the leader, "put one and the same object in the place of their ego ideal" and identify "themselves with one another in their ego" (Freud, 1921, p. 116).

Freud linked the image of the leader to a "primal father" of a "primal horde" of prehistoric times (Freud, 1912-1913), which in reality has never been observed. Such a father prevents his sons from satisfying their sexual impulses. Only the successor will have the possibility of sexual satisfaction. Freud also wrote how individuals in a large group develop new experiences such as losing distinctiveness and being subjective to suggestions. If mutual ties between the members cease to exist, panic starts. Freud also pointed out how belonging to a large group creates prejudice toward strangers. It was Robert Waelder (1936) who first stated that Freud was describing regressed large groups.

Reading Freud's ideas about large-group psychology reminded me of the May Day dance, a tradition that goes back centuries. Dancers, often holding ribbons, circle around a tall pole. The pole's symbolism has been mentioned by various scholars from different fields. Thinking of Freud's description of large-group psychology, let us consider the pole as representing the primal father.

I have expanded the picture of the maypole dance by imagining a canvas extending from a tall pole out over all the people, forming a huge tent (Volkan 1988, 2019, 2020b). I also imagined how we learn to wear two layers, like fabric, from the time we are children. The first layer, the individual layer, fits each of us snugly, like clothing. It is a person's core individual identity. The second layer, the canvas of tent is shared by everyone under the tent, including the political leader, the pole. The canvas represents large-group identity.

Anna Freud (1954), in discussing the "widening scope of psychoanalysis," illustrated bias toward treating only neurotic patients instead of struggling with new technical problems. Her attitude could not be maintained. As time went on, with the influence of new theories, new psychoanalytic "schools" and other factors such as economic ones, many psychoanalysts continued or began to treat individuals with narcissistic and borderline personality organizations, as well as individuals with extremely traumatic early childhood histories. This, and further realization that a child's mind does not evolve without his or her interactions with the mother and/or a mothering person, increased psychoanalysts' attention to preoedipal issues. Some authors postulated that people experience their large group as a maternal ego ideal or a breast-mother who repairs narcissistic injuries (Anzieu, 1984; Chasseguet-Smirgel, 1973; Kernberg, 2003a, 2003b).

I imagined that in individual psychology, the canvas of the tent can be perceived as a breast-mother and the pole can remain as a symbol of a 
primal father. But my work in large-group psychology directed me to focus on the canvas of the tent representing the large-group identity that develops in childhood or adulthood and is shared by thousands or millions of people, including the political leader, the pole.

There are subgroups and subgroup identities, such as professional identities or being followers of a sports team under a typical large-group tent. A person can change a subgroup identity either with or without anxiety. After going through the adolescence passage however, a person cannot change a core large-group identity that developed in childhood, even if he or she, due to special life experiences, wishes to hide or deny it (Volkan, 2017, 2020b). If the person becomes an immigrant or refugee, due to personal issues as well as the situation in the new country, he or she may make a good or bad adaption to developing bi-culturalism. As I already mentioned, some adults put themselves under a new tent when they become members of religious cults or terrorist organizations, and they modify the influence of their large-group identity which had developed in childhood.

\section{WHEN INDIVIDUALS AND LARGE GROUPS GRASP LARGE-GROUP IDENTITIES}

Under certain circumstances individuals subsume their personal identities behind their large-group identities and hold fast to large-group identity over individual identity openly or in hidden ways. In the 1970s, soon after I became a psychoanalyst and was living in Virginia, a young woman who had been married a year became my analysand. Her Jewish parents had moved to Virginia before their daughter was born. The father believed that, as a Jewish man in the South, he would not draw enough customers for his business, so he and his wife changed their names and presented themselves as Christians. When their daughter was growing up, they taught her to pretend to be a non-Jewish person when outside the family home. As a young woman she married a wealthy Christian man who was prejudice toward black persons and Jews. The reason she sought treatment was her secret preoccupation with her large-group identity that she clung to. Even before she finished her analysis, she divorced her husband and became a successful woman who was very comfortable with her Jewish identity.

While working with this patient I became very aware of my own on-andoff struggle in adjusting to life as an immigrant in a new country and my attempts to hide my Cypriot-Turkish identity while trying to develop a United States identity. But this was impossible because of my accent when I spoke English. At this time, I was not yet comfortable with bi-culturalism. Later, when I had the opportunity to study the psychology of refugees and 
immigrants, as expected, I noted that large-group identity issues are their main psychological problems, along with many realistic ones such as finances and health (Volkan, 2017).

After I became involved in bringing together influential representatives of opposing national groups for unofficial dialogues, I began noticing very clearly how and why individuals grasp onto their large-group identities. Here is a very good example: In 1983 I was conducting a meeting between Israelis, Egyptians, and Palestinians in Switzerland. A Palestinian, who was attending the dialogue series for the first time was sitting next to a very famous retired Israeli military man. He began describing life in Gaza and added that he was not allowed to carry a passport to indicate his nationality. As he stated "I must travel with a document in which my national identity is indicated as "undetermined" he put his right hand into his trouser pocket and declared: "As long as I have this, you can't take my Palestinian identity from me. I can tolerate anything." I would learn that what the Palestinian had touched was a small piece of stone on which the Palestinian flag colors were painted. It was a symbol of his Palestinian large-group identity. I learned that at that time many Palestinians in Gaza carried similar stones.

Psychoanalysts have written about avoiding the examination of tragic historical events, especially the Holocaust, in the clinical setting because they induce anxiety (Moses, 1984; Blum, 1985; Loewenberg, 1991; Bohleber, 2007; Prince, 2009). In July 1995, an organization called Psychotherapeutischer Arbeitskreis für Betroffene des Holocaust, PAKH e.V. (Psychotherapeutic Study Group of Persons Affected by the Holocaust) was founded in Germany by ten psychoanalytic psychotherapists. Four of them were Jewish-Germans. Their main aim was to deal, in the clinical setting, with the "silence" related to the impact of World War II and the Holocaust on the offspring of survivors and perpetrators in Germany. They faced emotional difficulties among themselves while preparing an international symposium about their work and asked for my help. In February 1997 I began meeting with this group-several full days each time-on four occasions. One of the first things I noticed was how the members of PAKH, while discussing their project, would bring to life among themselves largegroup identity issues experienced during the Third Reich, although half a century had passed since then. Their grasping onto these identities was the obstacle to organizing their symposium (Volkan, Ast, \& Greer, 2002). PAKH's international symposium did take place in Düsseldorf in August 1998. It was named Das Ende der Sprachlosigkeit [The end of speechlessness] (Opher-Cohn, Pfäfflin, Sonntag, Klose \& Pogany-Wnendt, 2000). I still keep in contact with PAKH members and continue to appreciate and admire their ongoing work. 


\section{VARIATIONS OF SHARED CATASTROPHES AND CHOSEN TRAUMAS}

Besides grasping onto large-group identity when conflicts exist between opposing large groups, there are other themes of large-group psychology, such as the leader-follower relationship. Since the pole is involved in keeping the tent steady or shaking it, the examination of the personality organization of a leader sometimes becomes a crucial part of large-group psychology (Volkan, Akhtar et al., 1999; Volkan, 2020b). For example, psychoanalysts have studied Adolph Hitler's personality organization (Langer, 1972; Volkan, Ast, \& Greer, 2002). At the present time, Donald Trump's role and involvement in shaking the American tent, creating a severe societal division, and stimulating the storming of the United States Capitol on January 6, 2021 is being discussed regularly on various forums. Earlier I wrote about the two-way street relationship between a political leader and the followers. The two-way traffic may become congested due to the psychological make-up of the leader or due to shared conscious and unconscious needs of the followers. I illustrated how some followers' basic trust in the leader turns into "blind trust" (Volkan, 2004, 2020b). In this paper, rather than stay with the leader-followers theme, I will instead focus on shared major traumas and their impacts on large groups.

Shared catastrophes are of various types. Some are from natural causes, such as earthquakes, storms, floods, and volcanic eruptions. Some are accidental man-made disasters, like the 1986 Chernobyl accident that sent massive clouds of radioactive dust into the atmosphere. The murder of a leader, or of a person who functions as a "transference figure" for many members of a large group, also provokes individualized as well as societal responses - as did the assassinations of John F. Kennedy (Wolfenstein \& Kliman, 1965) and Martin Luther King Jr. in the United States and Yitzhak Rabin in Israel (Erlich, 1998; Raviv, Sadeh, Raviv, Silberstein \& Diver, 2000).

My focus here will be on shared experiences of disaster that are due to the deliberate actions of another large group, as in ethnic, national, religious, or ideological conflicts. Such intentional catastrophes themselves range from the traumatized group actively fighting its enemy, to the traumatized group rendered passive and helpless. Sometimes they lead to new genocides. Today human beings' common enemy is COVID-19. Later I will refer to how this virus has also impacted large-group identity issues.

When nature shows its fury and people suffer, victims tend ultimately to accept the event as fate or as the will of God (Lifton \& Olson, 1976). After man-made accidental disasters, survivors may blame a small number of individuals or governmental organizations for their carelessness; but even then, there are no Others who have intentionally sought to hurt the victims. 
When a trauma results from war or other ethnic, national, religious, or ideological conflict, however, there is an identifiable enemy large group that has deliberately inflicted pain, suffering, and helplessness on its victims. A trauma at the hand of the Other impacts large-group identity issues in ways different from the effects of natural or accidental disasters. And sometimes, accompanying events and different types of disasters intertwine.

Starting in the 1980s and until the early 2000s, while my multidisciplinary team from the University of Virginia and I were bringing together influential representatives of large groups in conflicts for years-long dialogues, I learned that behind observable factors like politics, economics, and legal issues, the central psychological factor in starting and keeping alive large-group conflicts is the need to protect and maintain large-group identity. During these gatherings, my team members and I also observed how a participant, after perceiving a threat against his or her large-group identity, would start talking, with accompanying emotions, about a trauma suffered by his or her ancestors at the hand of an enemy centuries ago. I named images of such traumas "chosen traumas." The word "chosen" refers to the shared mental image of the large group's real, fantasized or even mythologized historical event, which, as it is transmitted from one generation to the next, undergoes a "change of function" (Waelder, 1936) and becomes a most significant large-group identity marker. It is stitched on the large group's tent canvas.

I recall how, during the unofficial diplomatic dialogues between Russians and Estonians following the collapse of the Soviet Union, a delegate who was a powerful member of the Russian parliament suddenly started talking about the Tatar-Mongol yoke of 1237-1242. When we brought influential Turkish and Greek representatives together for unofficial talks, we observed some Greek delegates' preoccupation with the Greeks' chosen trauma, the Ottomans' conquering of Constantinople, today known as Istanbul, in 1453.

Chosen traumas are linked to entitlement ideologies. Entitlement ideologies refer to a shared sense of entitlement to recover what was lost in reality and in fantasy during the ancestors' collective trauma that evolved as a chosen trauma and how it is reflected onto the present sense of entitlements while relating to a current Other. What is fantasized from the past, felt now, and expected for the future come together in what I call a time collapse (Volkan, 1997, 2020b). During this process, perceptions and fears may become magnified and exaggerated. The time collapse leads to obstacles against participants' exploring peaceful solutions. Generally speaking, during official diplomatic negotiations facilitators do not pay attention to or even realize the existence of such psychological resistances.

Serbian leader Slobodan Milošević, who had come to power in 1987 with the help of some Serbian academicians, the Serbian Orthodox Church, 
and malignant propaganda, created a time collapse for the Battle of Kosovo, the Serbian chosen trauma that took place in 1389. The Serbian entitlement ideology, called "Christoslavism" (Sells, 2002) was inflamed, which gave permission to create a "Greater Serbia." The six-hundred-year-old remains of Prince Lazar (most likely some bones) who was the leader of Serbians during the Battle of Kosovo, had been enshrined north of Belgrade. As the six-hundredth anniversary of the Battle of Kosovo approached in 1989, these bones were placed in a coffin and taken, over the course of the year, to almost every Serb village and town where they were received by huge crowds of mourners dressed in black. Again, and again during this long journey, Lazar's remains were symbolically buried and reincarnated, until they were buried for good at the original battleground in Kosovo on June 28, 1989. The Serbian people began feeling, without being intellectually aware of it, that the defeat at the Battle of Kosovo had occurred only recently, a development made possible by the fact that the chosen trauma had been kept effectively alive for centuries.

A time collapse shared by a large group sometimes leads to "dehumanization" of the Other and "purification" from the Other. Atrocities would eventually be committed against Bosnian and Kosovar Muslims, whom modern Serbs came to perceive as extensions of the Ottoman enemy of distant history. The aim was to reinforce and reinvigorate the Serbian largegroup identity by the lasting emotional power of the shared image of a centuries-old event-at terrible cost to non-Serbs, especially at Srebrenica (Volkan, 1996, 2019).

\section{UNDIGESTED TRAUMAS AND LARGE-GROUP MOURNING}

The term "chosen trauma" does not apply to fairly recent shared traumas at the hands of others that still induce intensely personal feelings in people. For example, the Holocaust is not a chosen trauma. Descendants still have pictures and belongings from survivors; survivors' stories are still "alive." Because the Jewish people were the victims of the Holocaust, this horrible historical event is a marker of their shared identity. A large group's preoccupation with an undigested trauma, directly or indirectly, is related to continuing difficulties related to large-group mourning. There have been countless ways to recall and express feelings of mourning regarding the Holocaust-in religious or political ceremonies, in books, in poems, in art, in conferences. Visiting Yad Vashem in Jerusalem, for example, still induces strong feelings in Jewish people, and indeed in all those who allow themselves to feel the impact of the Holocaust. Yad Vashem is one of the shared linking objects that keeps the group's mourning alive (Volkan, 
2006b). Yad Vashem is not associated with keeping the wounds caused by the Holocaust alive in the hope of recovering what has been lost; it is not associated with a sense of revenge. Not every major trauma at the hand of the Other evolves as a chosen trauma centuries later.

\section{COVID-19 TRAUMA AND LARGE-GROUP IDENTITY}

When Jews were expelled from Spain and Portugal after the Alhambra Decree issued on March 31, 1492 by the joint Catholic Monarch of Spain, many of them were welcomed into the Ottoman Empire, and their descendants still live there with a large-group identity linked to traditions and pride. I have been the supervisor of some Turkish analysts treating several individuals who hold on to this unique large-group identity. It is beyond the scope of this paper to describe fully the analysands' reactions to the virus pandemic, but here I wish to illustrate how, when there is a new shared trauma, old shared traumas, especially those at the hand the Other, are recalled. The day after beginning analytic sessions via telecommunication rather than in-office visits, one Jewish analysand in Istanbul began thinking of Anne Frank. He felt that, by not being able to come to his analyst's office, he was forced to go into hiding, like Anne Frank had done. Some months after COVID-19 made a negative impact on his business, another Jewish analysand and his family spent a huge amount of money to buy a purebred Vizsla dog from Poland and bring it to Istanbul, believing that this dog would be the first one of its kind in Turkey. Vizslas were companions of the early warlords and barons in Hungary way back in the 14th century, and now they are known as "survivors." They survived the Ottoman Turks' occupation of Hungary (1526-1696), the Hungarian Revolution of 1848, World War I, World War II and the Hungarian People's Republic, and even being overrun by the popularity of English Pointers and German Shorthaired Pointers in the 1800s (Boggs, 1973). For this analysand, the Vizsla breed became a symbol for the Jewish peoples' survival in Istanbul.

Holocaust Memorial Day reminds me that the image of the Holocaust and that of Hitler have become symbols of horrible aggression in the minds of non-Jewish persons as well; such symbols appear in the dreams of many people. 


\section{LAST WORDS}

Once more, let us return to Sigmund Freud's writings. During his correspondence with Albert Einstein in 1932, he expressed pessimism about the role of psychoanalysis in preventing wars (Freud, 1933). I share this pessimism. However, my work in international relationships also has become a factor in realizing the necessity for psychoanalysts to contribute to an increasing need to find serious new ways for reducing and vaccinating against tensions between opposing large groups. The International Dialogue Initiative (IDI) was established in 2007, and since has been bringing together a group of psychoanalysts, political scientists, diplomats, sociologists, business persons and other professionals from eight different countries to observe and study the intertwining of large-group psychology with world affairs to learn how such circumstances are perceived by different large groups (www.internationaldialogueinitiative.com). For me the IDI represents my belief that when "neighbors" talk, they do not actually hurt and get rid of the Other; genocides are prevented.

\section{NOTE}

1. Vamik D. Volkan, M.D., is an Emeritus Professor of Psychiatry at the University of Virginia, Charlottesville, Virginia and an Emeritus Training and Supervising Analyst at the Washington Psychoanalytic Institute, Washington, DC. He is the Emeritus President of the International Dialogue Initiative and a former President of the Turkish-American Neuropsychiatric Society, the International Society of Political Psychology, the Virginia Psychoanalytic Society, and the American College of Psychoanalysts. He has authored numerous books, some include: Cyprus: War and Adaptation: A Psychoanalytic History of Two Ethnic Groups in Conflict (University of Virginia Press, 1979), Linking Objects and Linking Phenomena: A Study of the Forms, Symptoms, Metapsychology and Therapy of Complicated Mourning (International Universities Press, 1981), What Do You Get When You Cross a Dandelion with a Rose? The True Story of Psychoanalysis (Jason Aronson, 1984), Six Steps in the Treatment of Borderline Personality Organization (Jason Aronson, 1987), The Need to Have Enemies and Allies: From Clinical Practice to International Relationships (Jason Aronson, 1988), Bloodlines: From Ethnic Pride to Ethnic Terrorism (Farrar, Straus and Giroux, 1997), Blind Trust: Large Groups and Their Leaders in Times of Crises and Terror (Pitchstone, 2004), Killing in the Name of Identity: A Study of Bloody Conflicts (Pitchstone, 2006), Enemies on the Couch: A Psycho-Political 
Journey Through War and Peace (Pitchstone, 2013), Psychoanalysis, International Relations and Diplomacy: A Sourcebook on Large-Group Psychology (Karnac, 2014), A Nazi Legacy: Depositing, Transgenerational Transmission, Dissociation, and Remembering Through Action (Karnac, 2015), Immigrants and Refugees: Trauma, Perennial Mourning, and Border Psychology (Karnac, 2017), Ghosts in the Human Psyche: The Story of a 'Muslim Armenian' (Phoenix, 2019), and Large-Group Psychology, Racism, Societal Divisions, Narcissistic Leaders and Who We Are Now (Phoenix, 2020). He has also co-authored many books, a few are: Turks and Greeks: Neighbors in Conflict with N. Itzkowitz (The Eothern Press, 1994), Siblings in the Unconscious and Psychopathology with G. Ast (International Universities Press, 1997), Third Reich in the Unconscious: Transgenerational Transmission and its Consequences with G. Ast and W. F. Greer, Jr. (Brunner-Routledge, 2002), Religious Knives: Historical and Psychological Dimensions of International Terrorism with J. Suistola (Pitchstone, 2017), and Fundamentalism and Psychoanalysis with W. Bohleber and G. Leo (Frenis Zero Press, 2020).

\section{REFERENCES}

Akhtar, S. (1992). Broken structures: Severe personality disorders and their treatment. Northvale, NJ: Jason Aronson.

Akhtar, S. (1999). Immigration and identity: Turmoil, treatment and transformation. Northvale, NJ: Jason Aronson.

Anzieu, D. (1984). The group and the unconscious. London: Routledge \& Kegan Paul.

Bloom, P. (2010). How pleasure works: The new science of why we like what we like. New York: W. W. Norton.

Blum, H. (1985). Superego formation, adolescent transformation and the adult neurosis. Journal of the American Psychoanalytic Association, 33(4), 887-909.

Boggs, B. C. (1973). The Vizsla. Jackson, OH: Glenbrier Publishing Company. 2000.

Bohleber, W. (2007). Remembrance, trauma and collective memory: The battle of memory in psychoanalysis. International Journal of Psychoanalysis, 88(2), $329-352$.

Bolter, J. D. (1984). Turing's man: Western culture in the computer age. Chapel Hill, NC: University of North Carolina Press.

Brenner, I. (2014). Dark matters: Exploring the realm of psychic devastation. Oxford: Karnac.

Brenner, I. (Ed.). (2019). The handbook of psychoanalytic Holocaust studies: International Perspectives. New York: Routledge.

Çevik, A. (2003). Globalization and identity. In S. Varvin \& V. D. Volkan (Eds.), Violence or dialogue: Psychoanalytic insights to terror and terrorism (pp. 91-98). London: International Psychoanalysis Library. 
Chasseguet-Smirgel, J. (1973). The ego ideal: Psychological essay on the malady of the ideal. New York: W. W. Norton. 1984.

Emde, R. (1991). Positive emotions for psychoanalytic theory: Surprises from infancy research and new directions. Journal of the American Psychoanalytic Association (Supplement), 39, 5-44.

Erikson, E. H. (1956). The problem of ego identity. Journal of the American Psychoanalytic Association, 4, 56-121.

Erlich, H. S. (1998). Adolescents' reactions to Rabin's assassination: A case of patricide? In A. Esman (Ed.), Adolescent psychiatry: Developmental and clinical studies (pp. 189-205). London: The Analytic Press.

Freud, A. (1954). The widening scope of indications for psychoanalysis. In The writings of Anna Freud (Vol. 4, pp. 356-376). New York: International Universities Press. 1968. Also in Journal of the American Psychoanalytic Association, 2(4), 607-620.

Freud, S. (1912-1913). Totem and taboo. Standard Edition, Vol. 13, (pp. 1-161). London: Hogarth.

Freud, S. (1917). Taboo of virginity. Standard Edition, Vol. 11, (pp. 191-208). London: Hogarth.

Freud, S. (1921). Group psychology and the analysis of the ego. Standard Edition, Vol. 18, (pp. 65-143). London: Hogarth.

Freud, S. (1933). Why war? Standard Edition, Vol. 22, (pp. 195-216). London: Hogarth.

Freud, S. (1938). An outline of psycho-analysis. Standard Edition, Vol. 23, (pp. 139-207). London: Hogarth Press.

Greenspan, S. I. (1989). The development of the ego: Implications for personality theory, psychopathology and the psychotherapeutic process. Madison, CT: International Universities Press.

Grubrich-Simitis, I. (1979). Extremtraumatisierung als kumulatives Trauma. Psychoanalytische Studien über seelische Nachwirkungen der Konzentrationslagerhaft bei Überlebenden und ihren Kindern [Extreme traumatization as a cumulative trauma: Psychoanalytic studies on the mental effects of imprisonment in concentration camps on survivors and their children]. Psyche, 33(11), 991-1023.

Grünberg, K., \& Markert, F. (2017). Child survivors: Stolen childhood-scenic memory of the Shoah in Jewish child or adolescent survivors of Nazi persecution. American Journal of Psychoanalysis, 77, 105-127.

Horowitz, D. L. (1985). Ethnic groups in conflict. Berkeley: University of California Press.

Kernberg, O. F. (2003a). Sanctioned political violence: A psychoanalytic view-Part 1. International Journal of Psychoanalysis, 84(3), 683-698.

Kernberg, O. F. (2003b). Sanctioned political violence: A psychoanalytic view-Part 2. International Journal of Psychoanalysis, 84(4), 953-968.

Kestenberg, J. S., \& Brenner, I. (1996). The last witness: The child survivor of the Holocaust. Washington, DC: American Psychiatric Press.

Kinnvall, C. (2004). Globalization and religious nationalism: Self, identity, and the search for ontological security. Political Psychology, 25(5), 741-767.

Kogan, I. (1995). The cry of mute children. A psychoanalytic perspective of the second generation of the Holocaust. London: Free Association Books.

Kosiur, D. (1997). Understanding electronic commerce. Redmond, WA: Microsoft Press. 
Langer, W. C. (1972). The mind of Adolf Hitler: The secret wartime report. (Foreword by W. L. Langer and Afterword by R. G. L. Waite). New York: Basic Books.

Laub, D. (2018). Book Review: Not in my family: German memory and responsibility after the Holocaust, by R. Frie, New York, Oxford University Press, 2017, 312 pp. American Journal of Psychoanalysis, 78, 195-200.

Laub, D., \& Podell, D. (1997). Psychoanalytic listening to historical trauma: The conflict of knowing and the imperative act. Mind and Human Interaction, 8, $245-260$.

Lehtonen, J. (2003). The dream between neuroscience and psychoanalysis: Has feeding an infant impact on brain function and the capacity to create dream images in infants? Psychoanalysis in Europe, 57, 175-182.

Lifton, R. J., \& Olson, E. (1976). The human meaning of total disaster: The Buffalo Creek experience. Psychiatry, 39(1), 1-18.

Liu, J. H., \& Mills, D. (2006). Modern racism and neo-liberal globalization: The discourses of plausible deniability and their multiple functions. Journal of Community and Applied Social Psychology, 16(2), 83-99.

Loewenberg, P. (1991). Uses of anxiety. Partisan Review, 58(3), 514-525.

Morton, T. L. (2004). Prejudice in an era of economic globalization and international interdependence. In J. L. Chin (Ed.), The psychology of prejudice and discrimination: Disability, religion, physique, and other traits, Vol. 4 (pp. 135-160). Westport, CT: Praeger. 2005.

Moses, R. (1984). An Israeli psychologist looks back in 1983. In S. A. Luel \& P. Marcus (Eds.), Psychoanalytic reflections on the Holocaust: Selected essays (pp. 52-70). New York: Ktav Publishing.

Opher-Cohn, L., Pfäfflin, J., Sonntag, J. B., Klose, B., \& Pogany-Wnendt, P. (Eds.). (2000). Das Ende der Sprachlosigkeit? Auswirkungen traumatischer Holocausterfahrungen über mehrere Generationen [End of speechlessness? The effects of experiencing the Holocaust over several generations]. Gießen: Psychosozial Verlag.

Prince, R. (2009). Psychoanalysis traumatized: The legacy of the Holocaust. American Journal of Psychoanalysis, 69, 179-194.

Purhonen, M., Kilpeläinen-Lees, R., Valkonen-Korhonen, M., Karhu, J., \& Lehtonen, J. (2005). Four-month-old infants process own mother's voice faster than unfamiliar voices: Electrical signs of sensitization in infant brain. Cognitive Brain Research, 24(3), 627-633.

Ratliff, J. M. (2004). The persistence of national differences in a globalizing world: The Japanese struggle for competitiveness in advanced information technologies. Journal of Socio-Economics, 33(1), 71-88.

Raviv, A., Sadeh, A., Raviv, A., Silberstein, O., \& Diver, O. (2000). Young Israelis' reactions to national trauma: The Rabin assassination and terror attacks. Political Psychology, 21(2), 299-322.

Sells, M. A. (2002). The construction of Islam in Serbian religious mythology and its consequences. In M. Shatzmiller (Ed.), Islam and Bosnia. Conflict resolution and foreign policy in multi-ethnic states (pp. 56-85). Montreal: McGill University Press.

Stapley, L. F. (2006). Globalization and terrorism: Death of a way of life. London: Karnac Books.

Stern, D. N. (1985). The interpersonal world of the infant: A view from psychoanalysis and developmental psychology. New York: Basic Books. 
Suistola, J., \& Volkan, V. D. (2017). Religious knives: Historical and psychological dimensions of international terrorism. Durham, NC: Pitchstone.

Volkan, V. D. (1981). Linking objects and linking phenomena: A study of the forms, symptoms, metapsychology and therapy of complicated mourning. New York: International Universities Press.

Volkan, V. D. (1988). The need to have enemies and allies: From clinical practice to international relationships. Northvale, NJ: Jason Aronson.

Volkan, V. D. (1996). Bosnia-Herzegovina: Ancient fuel of a modern inferno. Mind and Human Interaction, 7, 110-127.

Volkan, V. D. (1997). Bloodlines: From ethnic pride to ethnic terrorism. New York: Farrar, Straus and Giroux.

Volkan, V. D. (2004). Blind trust: Large groups and their leaders in times of crises and terror. Charlottesville, VA: Pitchstone.

Volkan, V. D. (2006a). Killing in the name of identity: A study of bloody conflicts. Charlottesville, VA: Pitchstone.

Volkan, V. D. (2006b). What some monuments tell us about mourning and forgiveness. In E. Barkan \& A. Karn (Eds.), Taking wrongs seriously: Apologies and reconciliation (pp. 115-131). Stanford, CA: Stanford University Press.

Volkan, V. D. (2013). Enemies on the couch: A psycho-political journey through war and peace. Durham, NC: Pitchstone.

Volkan, V. D. (2017). Immigrants and refugees: Trauma, perennial mourning, and border psychology. London: Karnac.

Volkan, V. D. (2019). Large-group identity, who are we now? Leader-follower relationship and societal-political divisions. American Journal of Psychoanalysis, 79(2), 139-155.

Volkan, V. D. (2020a). A non-Jewish view. In I. Brenner (Ed.), The handbook of psychoanalytic Holocaust studies (pp. 25-31). New York: Routledge.

Volkan, V. D. (2020b). Large-Group psychology, racism, societal divisions, narcissistic leaders and who we are now. London: Phoenix.

Volkan, V. D., Akhtar, S., Dorn, R. M., Kafka, J. S., Kernberg, O. F., Olsson, P. A., Rogers, R. R., \& Shanfield, S. (1999). The psychodynamics of leaders and decision-making. Mind and Human Interaction, 9, 129-181.

Volkan, V. D., Ast, G., \& Greer, W. F., Jr. (2002). Third Reich in the unconscious: Transgenerational transmission and its consequences. New York: BrunnerRoutledge.

Waelder, R. (1936). The principle of multiple function: Observations on overdetermination. Psychoanalytic Quarterly, 5(1), 45-62.

Werman, D. S. (1988). Freud's "narcissism of minor differences:" A review and reassessment. Journal of the American Academy of Psychoanalysis, 16(4), 451-459.

Wolfenstein, M., \& Kliman, G. (Eds.). (1965). Children and the death of a president: Multi-disciplinary studies. Garden City, NY: Doubleday.

Publisher's Note Springer Nature remains neutral with regard to jurisdictional claims in published maps and institutional affiliations. 